\title{
Influence of different methods of application of effective microorganisms in nutrition of wheat on weight by 1000 grains, yield, and content of crude wheat proteins (TRITICUM SP)
}

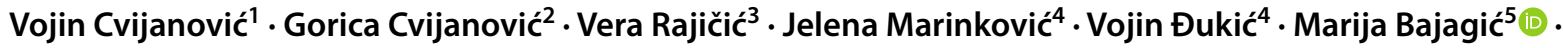 \\ Nenad Đurić ${ }^{6}$
}

Received: 9 June 2021 / Accepted: 8 November 2021 / Published online: 24 January 2022

(c) The Author(s) 2022

\begin{abstract}
The research was carried out in three vegetative seasons 2015/16, 2016/17, and 2018/19, on an experimental plot in Padinska Skela, Belgrade, Serbia. The supplement included four NPK treatments $\left(\mathrm{kg} \mathrm{ha}^{-1}\right)$ and foliar treatment with effective microorganisms (EM $71 \mathrm{ha}^{-1}$ ) T1-129: 60: 60; T2-129: 60: 60+1 EM; T3-106: 60: 60+2 EM ; T4-83: 60: 60+3 EM. Four wheat genotypes were sown (Ratarica, Pobeda, Nogal, and Apache). Thousand grain weight and grain yield were determined. The thousand grain weight (TGW) was in the variety Pobeda $43.73 \mathrm{~g}$, and the highest grain yield was in the variety Ratarica 7.02 tha $^{-1}$. Both varieties are medium late, bread varieties. The treatments have different effects on the studied variables. The TGW was the highest in the T2 treatment of $40.81 \mathrm{~g}$ and the grain yield in T3 of $6.62 \mathrm{t} \mathrm{ha}^{-1}$, which was at the level of statistical significance of $p>0.01$. The crude protein content was highest in the treatment of T2 $13.93 \%(p>0.01)$.
\end{abstract}

Keywords Wheat nutrition $\cdot$ Genotypes $\cdot$ Mass of 1000 grains $\cdot$ Wheat grain $\cdot$ Proteins

\section{Introduction}

In addition to corn and rice, wheat is the most common grain in the human diet. In human nutrition, wheat participates with 53\% in developed countries, and with $85 \%$ in less developed countries, of the total world production. (Pena 2007; Đurić et al. 2015). It is an important source of food in regions with rapid population growth, such as Africa, Asia, and Latin America (Donn et al. 2015). Climate change will

Communicated by M. Taylor.

Vojin Cvijanović

cvija91@yahoo.com

1 Institute for Science Application in Agriculture, Belgrade, Serbia

2 Institute of Information Technologies, University of Kragujevac, Kragujevac, Serbia

3 Faculty of Agriculture, University of Niš, Kruševac, Serbia

4 Institute of Field and Vegetable Crops, Novi Sad, Serbia

5 Faculty of Agriculture University, Bijeljina, Republic of Srpska

6 Institute for Vegetable Crops, Smederevska Palanka, Serbia expand the area of cereal cultivation while reducing yields in some southern parts of Europe (Lotze-Campen 2011). Gregory and George (2011) report that a 67\% increase in world wheat production will be needed to keep pace with world population growth by 2030 , where $21 \%$ yields by cultivating new areas, while $12 \%$ refers to intensive production of existing areas. The production and excessive application of $\mathrm{N}$ fertilizers contribute to a number of environmental problems (Xia et al. 2017). In order to meet the requirements of sustainable production for the preservation of the environment in the production technology, the use of microbiological preparations is of increasing importance. Previous research has shown that wheat can form a good association with diazotrophs in the soil. Using inoculation of wheat seeds with associative diazotrophs (Azotobacter chroococcum, Azospirillum lipoferum, Beijerinckia Derx, and Klebsiella planticola), the grain yield can be increased by $11.64 \%$ as well as the protein content in the grain by $6.40 \%$ (Cvijanović et al. 2008). According to research by Andres et al. (2009), inoculation of wheat seeds with species from the genera Azospirillum and Pseudomonas can increase root biomass by $40 \%$ and grain yield by $16 \%$. Inoculation of wheat seeds and intensification of plant germination increase the activity of the indigenous rhizosphere 
microbial population (Cvijanović et al. 2007), which synthesizes substances that promote growth, sideraphores, and antibiotics, which reduce the dependence on nitrogen and phosphorus fertilizers (Ahemad and Kibret 2014). Roljević et al. (2018) in 3-year research on the application of different groups of microorganisms in the nutrition of wheat and alternative cereals in the organic system, found an increase in grain yield by $13.9 \%$. Salmabi et al. (2018) found that the use of mixed culture as an inoculant of wheat seeds with active species Azotobacter, Agrobacterium, Bacillus, Pseudomonas, Trichoderma, Azospirillum, and Rhizophagus irregularis can significantly increase grain yield at the level of $r<0.05$ in relation to control. In recent years, more and more research has focused on the use of biostimulators that include live microbiological cultures, microbial extracts, products of their metabolism (hormones, antibiotics, indoleacetic acid, lactic acid, etc.). Biostimulants can stimulate plant growth and yield even when used in small amounts, so they can be used complementarily. Recognizing the need to use biostimulants in agriculture, the European Council of the Biostimulant Industry (EBIC 2012) recognized the need to establish a legal framework for the regulation of these products. Biostimulants are defined in the draft EU regulation 2016 as nutritional materials that affect nutritional processes regardless of their own nutrient content (Joner et al. 2019).

Biostimulators with effective microorganisms (EM) are increasingly used in agricultural production. Effective microorganisms are mixed cultures consisting of photosynthetic bacteria, lactic acid bacteria, yeasts, actinomycetes, and fermentation fungi. In the system of low input production, effective microorganisms are gaining more and more importance and occupy a significant place in agriculture (Calvo et al. 2014). The use of different groups of microorganisms can alleviate plant stress from abiotic factors, which is very important in times of climate change. Effective microorganisms belong to a group of microorganisms known as PGPR, because they produce growth hormones known as auxins, gibberellins, cytokinins, ethylene, and abscisic acid. Most research is focused on the incorporation of effective microorganisms into the soil. When introduced into the soil, they enhance the activity of mycorrhiza, suppress pathogenic fungi and nematodes, mineralize organic matter, promote and enhance indigenous microbial flora (Kumar and Sai Gopal 2015; Cvijanović et al. 2017). Effective microorganisms can be applied by foliar sprays, stimulating the activity of beneficial microorganisms in the plant philosphere. Yue et al. (2002) obtained an increase in the rate of photosynthesis in functional leaves during mid-vegetation by foliar application of EM in soybeans. They can be used as inoculants to increase the diversity of microflora and have an influence on physical and chemical characteristics of soil, decompose organic matter, stimulate plant growth and yield, decrease effects of monoculture, protect plants from diseases, and help remove physiological disorders in plants (Babalola 2010; Mayer et al. 2010; Schenck and Müller 2009).

Given that low input is the world's commonest method of production (low external input/low-input sustainable agriculture), the aim of this paper is to determine the importance of the use of effective microorganisms on grain yield and thousand grain weight.

\section{Materials and methods}

\section{Design of experimental research}

Experimental research was conducted during 2017-2019 in the experimental plots of the Institute of PKB Agroekonomik in Padinska Skela ( $\Psi \mathrm{N} 44^{\circ} 56^{\prime}, \lambda \mathrm{E} 25^{\circ} 28^{\prime}$ ). The area of the experimental plots was $576 \mathrm{~m}^{2}$, and the individual plots $5 \mathrm{~m}^{2}$. The plots are arranged according to the plan of divided plots in four repetitions. The pre-crop in each year of research was maize.

\section{Factor A}

The production of field crops largely depends on the meteorological conditions characteristic of different types of grain during the year, and especially during the vegetation period, so as a factor, they cannot be omitted in research of this type.

\section{Factor B}

Four varieties of wheat of good technological quality were sown (November 22, 2016; October 25, 2017; November 16, 2018): Ratarica-medium late winter bread wheat variety type $\mathrm{B}_{1}-\mathrm{A}_{2}$ selection of the PKB Agroekonomik Institute, Pobeda-selection of the Institute of Field Farming and Vegetables Novi Sad, medium late bread variety type $A_{1}-A_{2}$ with pronounced high adaptability to environmental conditions; Nogal-Nogal yunta quattro-selection of French early wheat variety type $A_{2}$. Apache—selection Limagrain France, medium late variety type $B_{1}$. All were sown at 400 plants $\mathrm{m}^{-2}$.

\section{Factor C}

For wheat nutrition as a basic fertilizer, a complex NPK fertilizer 15:15:15 was used in the amount of $400 \mathrm{~kg} \mathrm{ha}^{-1}$, which was applied during the basic tillage in the fall. In the spring, UREA $46 \mathrm{~N} \%$ and supplementary foliar feeding with microbiological preparation EM Aktiv $\left(61 \mathrm{ha}^{-1}\right)$ were used in wheat fertilization, which contains a mixture of a large group of effective microorganisms. (EM): Lactobacillus plantarum, Lactobacillus casei, Streptococcus lactis, Rhodopseudomonas palustris, Rodobacter 
sphaeroides, Saccharomyces carevisiae, Streptomyces albus, Streptomyces griseus, Aspergillus oryzae, Mucor hiemalis Bacillus subtilis, Bacillus megaterium, Azotobacter $s p$. The formed treatments are shown in Table 1 .

At the end of vegetation, TGW and yield at $13 \%$ moisture were measured, as well as the content of crude protein determined by the micro-Kjeldahl method (Bremner and Mulvanei 1982).

To evaluate the data, we used descriptive statistics and analysis of variance (ANOVA) in program DSAASTAT. Three-way ANOVA was used to test effects of genotype, treatment and growing season. All results were calculated at a significance level LSD of 0.01 and 0.05 .

\section{Results}

\section{Climate conditions (air temperature and precipitation)}

Differences between average air temperature and sum precipitation wheat vegetation (Fig. 1).

In the autumn of October-November 2017, the temperatures were optimal as well as the amount of precipitation. The warmest winter month was December $6.5{ }^{\circ} \mathrm{C}$, with a water deficit, of only $10.8 \mathrm{~mm}$ recorded. There was lower than average precipitation of $34.4 \mathrm{~mm}$ in April, but with the humidity that had been retained since March and a mean temperature of $13.9{ }^{\circ} \mathrm{C}$, good conditions were created for further crop development. The month of June had precipitation and a higher temperatures, which significantly affected

Table 1 Factor $\mathrm{C}$ divided into four treatments

\begin{tabular}{|c|c|c|c|c|}
\hline Treatments & $\begin{array}{l}\text { Before sowing NPK (kg } \\
\left.\mathrm{ha}^{-1}\right)\end{array}$ & $\begin{array}{l}\text { In supplementation UREA } \\
\mathrm{kg} \mathrm{ha}^{-1} \text { ) }\end{array}$ & EM Aktiv & $\begin{array}{l}\text { Total nutrients } \\
\mathrm{N}: \mathrm{P}_{2} \mathrm{O}_{5}: \mathrm{K}_{2} \mathrm{O}\end{array}$ \\
\hline T 1 & 400 & 150 & Control & 129: 60: 60 \\
\hline Т 2 & 400 & 150 & Stage: tillering begins & 129: $60: 60$ \\
\hline T 3 & 400 & 100 & Stage: tillering begins and stage: flowering & 106: 60: 60 \\
\hline $\mathrm{T} 4$ & 400 & 50 & $\begin{array}{l}\text { Stage: full tillering begins, stage: flowering and } \\
\text { stage: grain fill }\end{array}$ & 83: 60: 60 \\
\hline
\end{tabular}
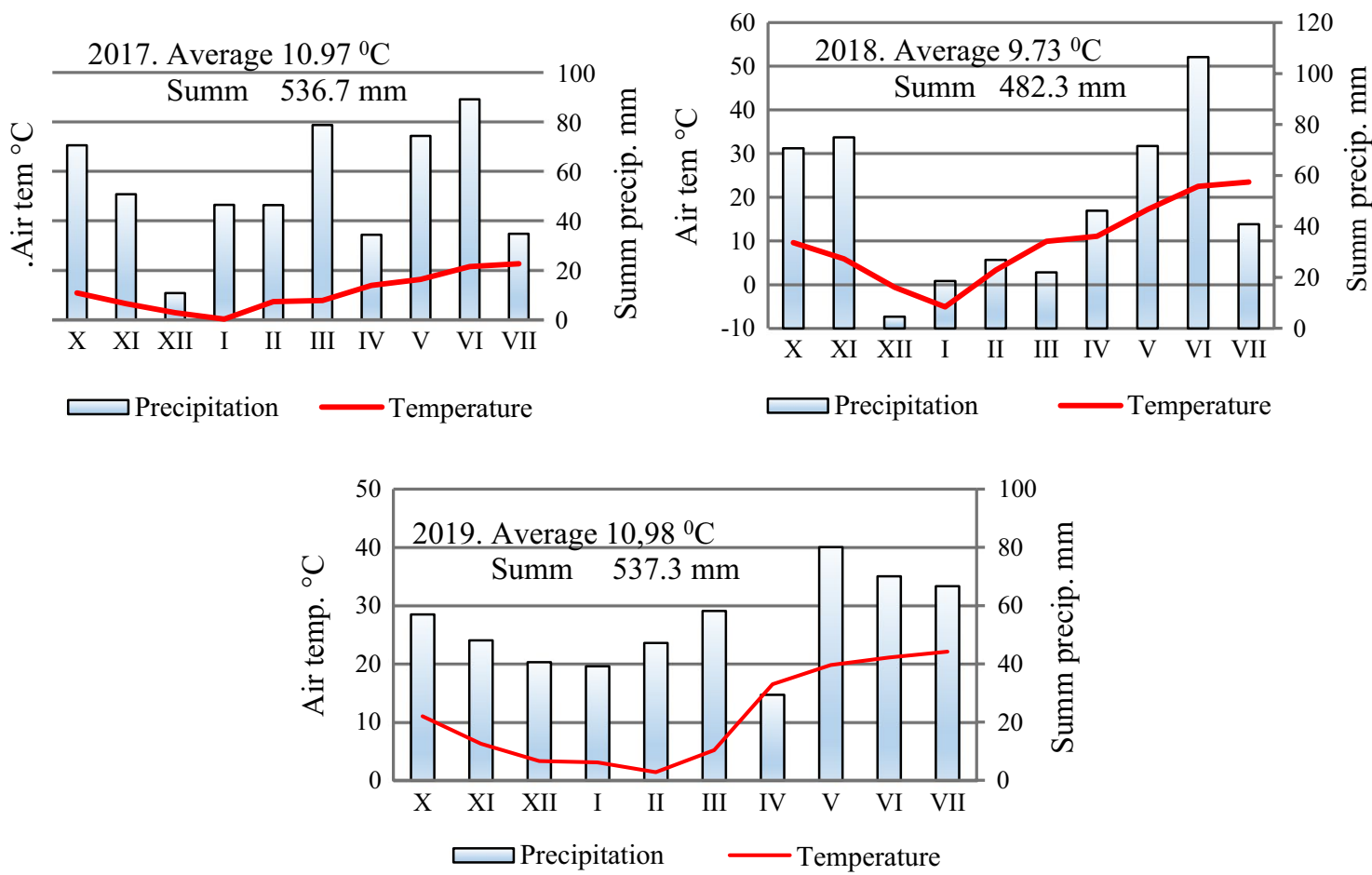

Fig. 1 Average air temperature $\left({ }^{\circ} \mathrm{C}\right)$ and sum precipitation $(\mathrm{mm})$ in wheat vegetation 2017-2019 year 
the grain development processes and significantly determined the grain yield. The mean summer air temperatures were within optimal limits with a relatively good precipitation distribution. The warmest month was June at $22.6{ }^{\circ} \mathrm{C}$. In 2018, December-February had frost temperatures from $-0.6{ }^{\circ} \mathrm{C}$ (December), to $-5.1{ }^{\circ} \mathrm{C}$ (January), without snow. Such climatic conditions lead to a decrease in the synthesis and consumption of sugar during the night, whereby their amount in the leaves and the nodules is reduced, which reduces the resistance to stress. During the period of grain filling and ripening, the average air temperature (June $22.5^{\circ} \mathrm{C}$ and July $23.5^{\circ} \mathrm{C}$ ) was higher than in 2017 and 2019. The highest amount of precipitation was $106.5 \mathrm{~mm}$ in June, with showers that affected the lodging of crops. The winter of 2019 (December-February) was quite mild with uniform average temperatures from 1.4 to $3.3^{\circ} \mathrm{C}$, without icy days. In this period, a total of $127.0 \mathrm{~mm}$ of precipitation was recorded with a good distribution of 39.2 to $47.2 \mathrm{~mm}$. The highest amount of precipitation was $80.1 \mathrm{~mm}$ in May, which created better conditions for grain development. The temperature rise continued in June $21.1^{\circ} \mathrm{C}$ and in July $22.1{ }^{\circ} \mathrm{C}$ quite uniform and characteristic for that period of the year. The amount of precipitation was less, which accelerated the ripening of the grain. The average air temperature and the amount of precipitation were quite uniform in 2017, but with a different distribution that significantly affected the differences in grain yield.

\section{Thousand grain weight (TGW)}

The TGW depends on the weight of the grains themselves as well as the biological characteristics of the genotype and to a greater or lesser extent on the environmental conditions. Analysis of TGW mass variance and yield based on LSD test showed that the main sources of variation (year, variety and fertilization) as well as their interactions have a statistically significant impact.

TGW is a productive trait that significantly affects the level of yield. The mean TGW of all examined parameters was $40.57 \mathrm{~g}$. TGW was the highest in 2019 at $44.34 \mathrm{~g}$ because this year in the period from April to July there was the highest amount of precipitation. Agrometeorological conditions in wheat vegetative growth had a statistically highly significant effect on differences in TGW the weight of 1000 grains. The lowest TGW was in 2018 (36.64 g), which is $10.58 \%$ less than in 2017 and $20.68 \%$ less than in 2019. These results were influenced by the uneven amount of precipitation in 2018 , because $106.5 \mathrm{~mm}$ of water sediment fell in June, which affected the lodging of plants and water retention on the surface. Although TGW is defined by the genetic material, it also depends on agroecological conditions, applied cropping practices and ranges over a wide interval. Varietal specificity had a highly significant effect on
TGW differences. Ratarica and Pobeda varieties had the best results. Variety Ratarica (41.82 g) showed higher TGW than cultivar Pobeda (43.73 g) by $4.63 \%$, cultivar Nogal $(37.30 \mathrm{~g})$ by $17.23 \%$ and cultivar Apache (39.43 g) by $10.90 \%$. All identified differences were at the level of high statistical significance $(p>0.01)$ (Table 2).

The application of foliar treatment with EM (factor C) significantly affected TGW at lower amounts of mineral nitrogen. On average for all years, the treatment T2 (40.81 g) and T3 $(40.74 \mathrm{~g})$ had the greatest impact. There was no statistical significance between the treatment $\mathrm{T} 2$ and $\mathrm{T} 3$, but in relation to the $\mathrm{T} 1(40.33 \mathrm{~g})$ control and $\mathrm{T} 4(39.14 \mathrm{~g})$ there was a significant difference $(p>0.01)$. TGW at T2 was greater than $1.19 \%$ (T1) to $4.29 \%$ (T4). T3 treatment increased TGW by $1.01 \%$ compared to $\mathrm{T} 1$ and by $4.08 \%$ compared to the $\mathrm{T} 4$ treatment.

\section{Grain yield}

Wheat is a plant that is grown in the open field, and the yield is a very quantitative character, so environmental factors can affect the parameters concerned with yields. Agrometeorological conditions had an impact on differences in yield levels over years that were not statistically significant. In 2018, the lowest yield of $6.22 \mathrm{tha}^{--1}$ was measured, i.e. the yield was $0.260 \mathrm{tha}^{-1}(4.18 \%)$ lower than in 2017 (6.48 $\left.\mathrm{t} \mathrm{ha}^{-1}\right)$, and $0.510 \mathrm{t} \mathrm{ha}^{-1}(8.19 \%)$ lower than in $2019(6.73 \mathrm{t}$ $\left.\mathrm{ha}^{-1}\right)$. This difference was influenced by a lower amount of precipitation in $2018(482.3 \mathrm{~mm})$. As temperature is a significant factor in achieving the yield, it is likely that the lower temperature in the vegetation in $2018\left(9.73^{\circ} \mathrm{C}\right)$ affected the achieved result. The obtained results are comparable with the results that obtained lower grain yields in the dry year than in the colder and wetter year.

Genotype (factor C) highly significantly determined grain yield. The cultivar Ratarica had the highest yield on average $7.02 \mathrm{t} \mathrm{ha}^{-1}$. Differences in yield level in relation to other varieties are statistically very significant. In relation to the variety Apache $\left(6.52 \mathrm{t} \mathrm{ha}^{-1}\right)$ and Pobeda $\left(6.50 \mathrm{t} \mathrm{ha}^{-1}\right)$ the difference was $7.66 \%$, and in relation to the variety Nogal $19.59 \%$. Wheat fertilization is an agrotechnical measure that affects the production of morphological and generative properties of soil. Previous research on the application of biofertilizers in combination with minerals has given good results.

The combined application of EM and mineral nitrogen in $\mathrm{T} 3$ influenced the achievement of the highest grain yield (6.62 $\mathrm{tha}^{-1}$ ), (Table 3).

The application of effective microorganisms twice in vegetation with $106 \mathrm{~kg} \mathrm{~N} \mathrm{ha}^{-1}$ had the greatest influence on the examined parameters. The highest TGW was recorded in the variety Pobeda $48.68 \mathrm{~g}$ in 2017 . The highest yield was the variety Ratarica $7.47 \mathrm{t} \mathrm{ha}^{-1}$ in 2019. The use of effective 
Table 2 Influence of examined variables on $\mathrm{TGW}(\mathrm{g})$

\begin{tabular}{|c|c|c|c|c|c|c|c|}
\hline \multirow[t]{2}{*}{ Year (A) } & \multirow[t]{2}{*}{ Genotype (B) } & \multicolumn{4}{|c|}{ Treatment (C) } & \multirow[t]{2}{*}{$\overline{\mathrm{X}} \mathrm{AB}$} & \multirow[t]{2}{*}{$\overline{\mathrm{X}} \mathrm{A}$} \\
\hline & & $\mathrm{T} 1$ & $\mathrm{~T} 2$ & $\mathrm{~T} 3$ & $\mathrm{~T} 4$ & & \\
\hline \multirow[t]{4}{*}{$2016 / 17$} & Ratarica & 42.00 & 41.00 & 42.00 & 42.00 & 41.75 & \multirow[t]{4}{*}{40.63} \\
\hline & Pobeda & 42.00 & 43.00 & 41.00 & 43.00 & 42.25 & \\
\hline & Nogal & 39.50 & 39.50 & 38.00 & 38.50 & 38.88 & \\
\hline & Apache & 39.50 & 39.50 & 39.50 & 40.88 & 39.63 & \\
\hline$\overline{\mathrm{X}} \mathrm{AC}$ & & 40.75 & 40.75 & 40.13 & 41.10 & & \\
\hline \multirow[t]{4}{*}{$2017 / 18$} & Ratarica & 37.63 & 36.35 & 47.30 & 48.58 & 37.60 & \multirow[t]{4}{*}{36.74} \\
\hline & Pobeda & 40.05 & 41.25 & 48.68 & 39.33 & 40.77 & \\
\hline & Nogal & 33.65 & 32.10 & 39.62 & 43.08 & 32.89 & \\
\hline & Apache & 34.70 & 35.83 & 41.18 & 44.14 & 35.69 & \\
\hline$\overline{\mathrm{X}} \mathrm{AC}$ & & 36.51 & 36.38 & 44.20 & 43.78 & & \\
\hline \multirow[t]{4}{*}{$2018 / 19$} & Ratarica & 45.33 & 38.00 & 38.43 & 39.18 & 46.10 & \multirow[t]{4}{*}{44.34} \\
\hline & Pobeda & 47.48 & 39.13 & 42.60 & 31.93 & 48.18 & \\
\hline & Nogal & 39.15 & 31.93 & 33.90 & 35.53 & 40.12 & \\
\hline & Apache & 42.93 & 36.16 & 36.70 & 36.16 & 42.97 & \\
\hline$\overline{\mathrm{X}} \mathrm{AC}$ & & 43.72 & 36.31 & 37.91 & 35.70 & $\overline{\mathrm{X}} \mathrm{B}$ & \\
\hline \multirow[t]{4}{*}{$\overline{\mathrm{X}} \mathrm{BC}$} & Ratarica & 41.65 & 41.17 & 42.58 & 43.58 & 41.82 & \\
\hline & Pobeda & 43.18 & 44.08 & 44.09 & 36.58 & 43.73 & \\
\hline & Nogal & 37.43 & 37.99 & 37.17 & 36.58 & 37.30 & \\
\hline & Apache & 39.04 & 40.01 & 39.13 & 39.83 & 39.43 & \\
\hline$\overline{\mathrm{X}} \mathrm{C}$ & & 40.33 & 40.81 & 40.74 & 39.14 & & \\
\hline \multirow[t]{2}{*}{ Average 2016-2019 } & & & & & & 40.57 & \\
\hline & $\mathrm{A}^{* *}$ & $\mathrm{~B} * *$ & $\mathrm{AB} * *$ & $\mathrm{C}^{* *}$ & $\mathrm{AC}^{* *}$ & $\mathrm{BC}^{\mathrm{ns}}$ & $\mathrm{ABC}^{\mathrm{ns}}$ \\
\hline $\mathrm{F}$ test & 0.772 & 0.000 & 0.000 & 0.000 & 0.000 & 0.232 & 0.765 \\
\hline LSD 0.01 & 1.30 & 2.06 & 2.91 & 0.92 & 1.30 & 1.83 & 2.59 \\
\hline LSD 0.05 & 1.14 & 1.54 & 2.18 & 0.69 & 0.98 & 1.39 & 1.97 \\
\hline
\end{tabular}

microorganisms as a supplement can be successful in different agroecological conditions.

Based on the analysis of world trends, the increase in wheat yield during the twenty-first century was the result of intensification of production. The application of biostimulators with EM can improve the development of production technology for the production of bread wheat genotypes in healthy food and environmental protection.

\section{Crude protein content}

In addition to the yield, the quality of wheat is of great importance for human health and well-being. According to many previous studies, agroecological factors and genotype have a significant influence on protein content.

In 3-year studies, the examined variables (years, genotype, and treatments) and genotype/treatment interaction had a highly significant effect on protein content. The highest protein content was determined in $2018,13.67 \%$, because the most rain fell in the period May-July. The variety Pobeda had the highest protein content of $13.69 \%$. On average, T3 treatment had a statistically highly significant effect on the protein content of $13.93 \%$ (Table 4 ).

\section{Cluster analysis}

Similarities and differences between the four examined four varieties, for three traits, by years, were determined by applying a hierarchical cluster analysis and are shown in Fig. 2.

Figure 2 shows that there are two clusters (I, II), of which cluster I includes the varieties Pobeda and Ratarica. Cluster II includes the varieties Nogal and Apache.

Based on such grouping, it is concluded that the varieties Pobeda and Ratarica have relatively more similar characteristics in the years of the field experiment in 2015, 2016 and 2017, compared to the varieties Nogal and Apache, which stood out in the second cluster in 2015, 2016 and 2017 years. Which means that these two clusters have a different genetic structure, i.e., that the varieties in these two clusters reacted differently to the applied amounts of fertilizers, which is most likely due to their genetics (Serbian and French). 
Table 3 Influence of examined variables on wheat grain yield $\left(\mathrm{t} \mathrm{ha}^{-1}\right)$

\begin{tabular}{|c|c|c|c|c|c|c|c|}
\hline \multirow[t]{2}{*}{ Year (A) } & \multirow[t]{2}{*}{ Genotype (B) } & \multicolumn{4}{|c|}{ Treatment $(\mathrm{C})$} & \multirow[t]{2}{*}{$\overline{\mathrm{X}} \mathrm{AB}$} & \multirow[t]{2}{*}{$\overline{\mathrm{X}} \mathrm{A}$} \\
\hline & & $\mathrm{T} 1$ & $\mathrm{~T} 2$ & $\mathrm{~T} 3$ & $\mathrm{~T} 4$ & & \\
\hline \multirow[t]{4}{*}{$2016 / 17$} & Ratarica & 6.63 & 7.07 & 7.38 & 6.85 & 6.98 & 6.48 \\
\hline & Pobeda & 6.46 & 6.17 & 6.62 & 7.13 & 6.59 & \\
\hline & Nogal & 6.29 & 6.52 & 6.64 & 6.85 & 6.57 & \\
\hline & Apache & 5.54 & 6.08 & 6.10 & 5.44 & 5.79 & \\
\hline$\overline{\mathrm{X}} \mathrm{AC}$ & & 6.23 & 6.46 & 6.69 & 6.57 & & \\
\hline \multirow[t]{4}{*}{$2017 / 18$} & Ratarica & 6.63 & 7.13 & 6.78 & 6.82 & 6.84 & 6.22 \\
\hline & Pobeda & 6.28 & 5.65 & 6.18 & 6.88 & 6.25 & \\
\hline & Nogal & 5.59 & 6.08 & 5.25 & 5.44 & 5.59 & \\
\hline & Apache & 5.88 & 6.19 & 6.10 & 6.67 & 6.21 & \\
\hline$\overline{\mathrm{X}} \mathrm{AC}$ & & 6.09 & 6.26 & 6.08 & 6.45 & & \\
\hline \multirow[t]{4}{*}{$2018 / 19$} & Ratarica & 7.24 & 7.06 & 7.47 & 7.18 & 7.23 & 6.73 \\
\hline & Pobeda & 6.28 & 6.43 & 7.01 & 6.91 & 6.66 & \\
\hline & Nogal & 6.67 & 6.45 & 6.73 & 7.26 & 6.78 & \\
\hline & Apache & 6.04 & 6.12 & 7.14 & 5.63 & 6.23 & \\
\hline$\overline{\mathrm{X}} \mathrm{AC}$ & & 6.56 & 6.51 & 7.09 & 6.75 & $\overline{\mathrm{X}} \mathrm{B}$ & \\
\hline \multirow[t]{4}{*}{$\overline{\mathrm{X}} \mathrm{BC}$} & Ratarica & 6.83 & 7.09 & 7.21 & 6.95 & 7.02 & \\
\hline & Pobeda & 6.34 & 6.08 & 6.60 & 6.98 & 6.50 & \\
\hline & Nogal & 5.72 & 6.09 & 6.16 & 5.50 & 5.87 & \\
\hline & Apache & 6.28 & 6.38 & 6.49 & 6.93 & 6.52 & \\
\hline$\overline{\mathrm{X}} \mathrm{C}$ & & 6.29 & 6.41 & 6.62 & 6.59 & & \\
\hline \multirow[t]{2}{*}{ Average 2017-2019 } & & & & & & 6.48 & \\
\hline & $\mathrm{A}^{* *}$ & $\mathrm{~B} * *$ & $\mathrm{AB}^{*}$ & $\mathrm{C}^{* *}$ & $\mathrm{AC}^{\mathrm{ns}}$ & $\mathrm{BC}^{\mathrm{ns}}$ & $\mathrm{ABC}^{\mathrm{ns}}$ \\
\hline F test & 0.979 & 0.000 & 0.028 & 0.000 & 0.527 & 0.110 & 0.186 \\
\hline LSD 0.01 & 0.91 & 0.40 & 0.57 & 0.26 & 0.36 & 0.51 & 0.72 \\
\hline LSD 0.05 & 0.80 & 0.30 & 0.42 & 0.19 & 0.27 & 0.39 & 0.55 \\
\hline
\end{tabular}

\section{Discussion}

Due to the great importance of commercial wheat, research should focus on determining the compatible relationship of wheat genotype and group of microorganisms that can be applied with foliar sprays to achieve economically viable yield. In addition to the genotype, the grain yield of winter wheat is greatly influenced by the fertilization system, which is one of the key factors that affect the level of yield and its quality, but it should be harmonized with climatic and soil conditions and variety requirements (Djuric et al. 2018).

Due to the high cost of fertilizers and the awareness of supporting sustainable agriculture and reduced pollution, in which research is growing, one of the possibilities would be the use of effective microorganisms. Considering that Serbia is in the process of joining the EU, in terms of research, it monitors fertilization measures, while at the state level, measures have not yet been prescribed. The level of grain yield, and the protein content is significantly affected by inoculation of wheat seeds with the genus Azotobacter diazotrophs (Singh et al. 2007) and Azospirillum (Sharma et al. 2007). It can be concluded that in different agroecological conditions, the application of effective microorganisms as a supplement can replace $23-46 \mathrm{~kg} \mathrm{~N} \mathrm{ha}^{-1}$. Bacterization of wheat with diazotrophs does not always show the expected results, and the complexity of the relationship between wheat and bacteria is the reason for that (Nemeth 2006).

In all examined variables, the best results were in the cultivar Ratarica and Pobeda. The application of effective microorganisms is a cheap and simple technique that is used and that does not pollute and falls into a sustainable context. By including effective microorganisms in wheat production, the quality and quantity of different wheat genotypes can be significantly improved. Grain yield was already $5.24 \%$ higher than at T1 $\left(6.29 \mathrm{t} \mathrm{ha}^{-1}\right), 3.27 \%$ from T2 $\left(6.41 \mathrm{tha}^{-1}\right)$ and $1.53 \%$ from $\mathrm{T} 4$ treatment $\left(6.59 \mathrm{t} \mathrm{ha}^{-1}\right)$. Similar results were obtained by Teixeira Filho et al. (2017) where only wheat was inoculated with Azospirillum brasilense species and found that a higher yield was achieved with less than $139 \mathrm{~kg} \mathrm{~N} \mathrm{ha}^{-1}$ in wheat supplementation. In two-year studies of the effect of water efficiency (WUE), biological and chemical fertilizers in different moisture regimes, the obtained results show an increase in wheat grain yield in treatments with a combination of biofertilizers Azotobacter 


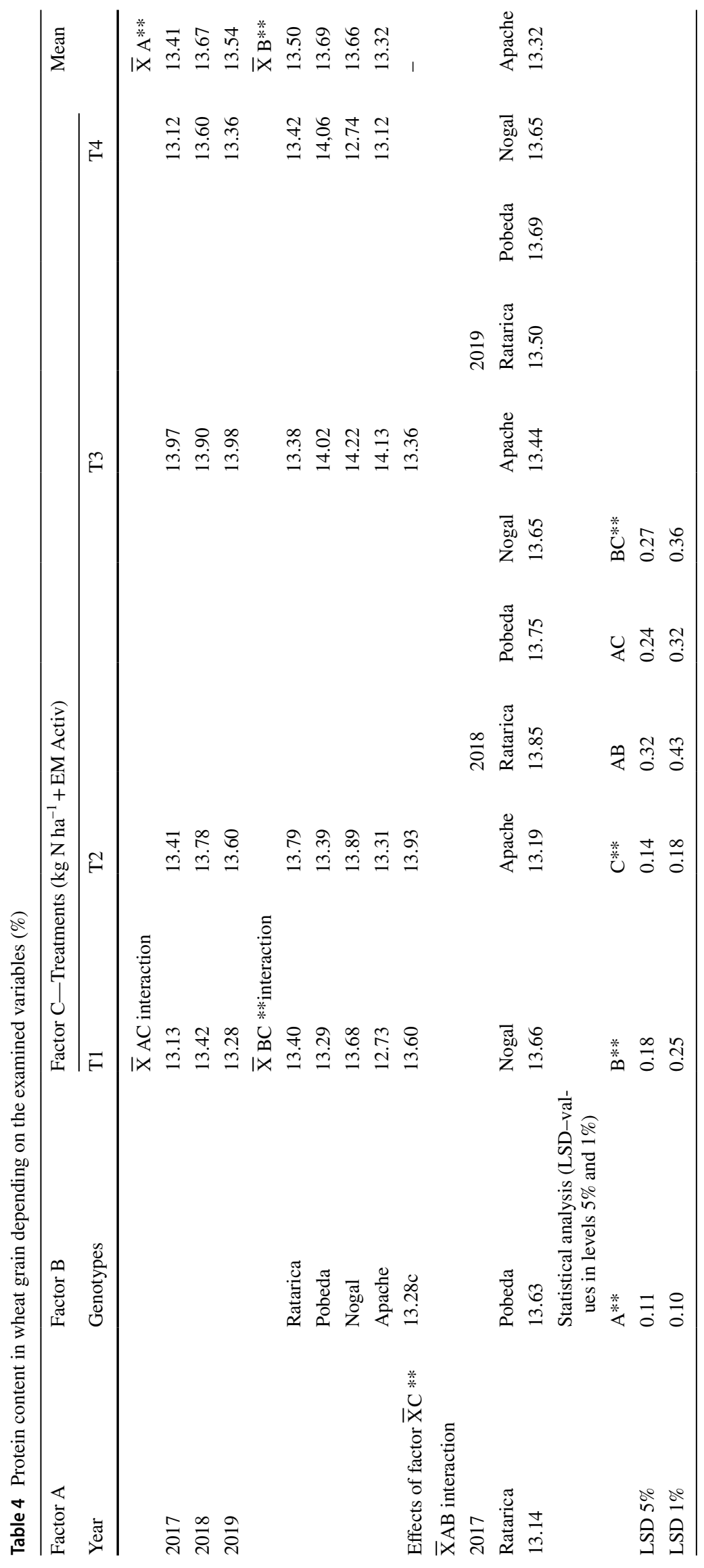


Fig. 2 Dendrogram of productive traits in 4 wheat varieties

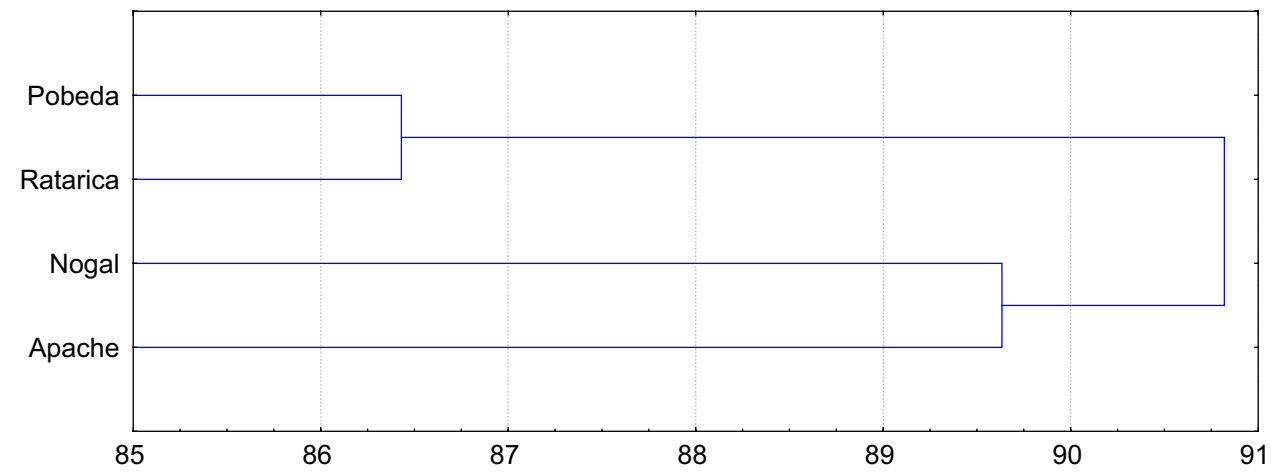

and Phosphobacteria, of $61.28 \%$ and $16.13 \%$, compared to the control (Moradgholi et al. 2021). The same authors state that Azotobacter and phosphobacteria biofertilizers, alone or in combination, increased the grain yield, biological yield, harvest index, water use efficiency and protein percentage in the wheat cultivar Arg. Mohammadi et al. (2011) found that the variety and medium/variety interaction for yield was highly significant 24 wheat genotypes, with an estimated heritability of $56.9 \%$.

In different agrometeorological conditions, the application of effective microorganisms several times in the growth period through the leaves can alleviate the stress of plants and achieve economically significant yields. Mladenov et al. (2014) found that the decrease in wheat yield as a result of rain $\left(107.6 \mathrm{l} / \mathrm{m}^{2}\right)$ in the phase of full maturity occurs due to grain shedding or activation of physiological processes in the grain, as well as plant traits (position of classes at full maturity, grain size, propensity to shed). The same authors on the basis of the linear regression concluded each $1 / \mathrm{m}^{2}$ in rain during the grain filling stage reduces the yields of $10 \mathrm{~kg} \mathrm{ha}^{-1}$ $(0.12 \%)$ and $10 \mathrm{l} / \mathrm{m}^{2}$ reduces the yield of $100 \mathrm{~kg} \mathrm{ha}^{-1}(1.2 \%)$. In two years of research by Đurić et al. (2017) on the influence of agrometeorological conditions, it was found that in the vegetative season with more precipitation than $176 \mathrm{~mm}$, and average temperatures lower by $3.1^{\circ} \mathrm{C}$, the $\mathrm{TGW}$ had higher values. Mohammadi et al. (2019) concluded that the characteristics of genotypes of wheat have a great influence than years as a factor. According to their research, the results show that efficiency of photosystem II and thousand-kernel weight were positively associated with grain yield, while heading date, plant height and canopy temperature were negatively associated with grain yield under drought conditions.

Zonuz et al. (2014) concluded that the use of biofertilizers and nitrogen fertilizers in certain combinations, in the phase of germination and flowering of wheat, leads to the full development of plants, increased number of pods, high grain mass. Xiaohou et al. (2001) conducted research in China to determine the effects of foliar application of effective microorganisms on yield and its quality in the production of tea, cabbage and sweet corn and found a yield increase of $25 \%, 14 \%$, and $12.5 \%$. Lim et al. (1999) studied the effects of different EM applications on rice and maize yields. The yield of both species increased by $7.2-7.4 \%$ in seed treatment, $7.1-7.4 \%$ in seedling treatment.

In addition, they significantly affect the protein content. Evers (2000) found that the shape and size of grains also affect the protein content, and indirectly the baking quality of the final products.

During the treatment with $106 \mathrm{~kg} \mathrm{~N} \mathrm{ha}^{-1}$ and two foliar treatments with effective microorganisms, a highly significantly higher protein content of $13.93 \%$ was determined. Monaghan et al. (2001) found that advanced wheat cultivation technologies, including different modern genotypes, can increase grain protein concentration and grain yields. According to Smutná and Tokatlidis (2010), genotypes with good yielding performance and protein concentration should be selected.

Acknowledgements The paper is part of the research of Project No. 451-03-68 /2020-14/200378, and TR 31092 funded by the Ministry of Science and Environmental Protection of the Republic of Serbia.

Open Access This article is licensed under a Creative Commons Attribution 4.0 International License, which permits use, sharing, adaptation, distribution and reproduction in any medium or format, as long as you give appropriate credit to the original author(s) and the source, provide a link to the Creative Commons licence, and indicate if changes were made. The images or other third party material in this article are included in the article's Creative Commons licence, unless indicated otherwise in a credit line to the material. If material is not included in the article's Creative Commons licence and your intended use is not permitted by statutory regulation or exceeds the permitted use, you will need to obtain permission directly from the copyright holder. To view a copy of this licence, visit http://creativecommons.org/licenses/by/4.0/.

\section{References}

Ahemad M, Kibret M (2014) Mechanisms and applications of plant growth promoting rhizobacteria: current perspective. J King Saud Univ 26:11-20. https://doi.org/10.1016/j.jksus.2013.05.001

Andres N, Alejandra Latrónico Ines García de S (2009) Inoculation of wheat with Azospirillum brasilense and Pseudomonas fluorescens: 
impact on the production and culturable rhizosphere microflora. Eur J Soil Bio; 45(1):44-51.https://doi.org/10.1016/j.ejsobi.2008. 11.001

Babalola OO (2010) Ethylene quantification in three rhizobacterial isolates from Striga hermonthica-infested maize and sorghum. Egypt J Biol 11:1-5

Bremner JM, Mulvaney CS (1982) Total nitrogen. In: Page AL, Miller RH, Keeny DR (eds) Methods of soil analysis. American Society of Agronomy and Soil Science Society of America, Madison, pp $1119-1123$

Calvo P, Nelson L, Kloepper JW (2014) Agricultural uses of plant biostimulants. Plant Soil 383:3-41

Cvijanović G, Milošević N, Đalovic I, Cvijović M, Paunović A (2008) Nitrogenization and $\mathrm{N}$ fertilization effects on protein contents in wheat grain. Cereal Res Commun 36:251-254. https://doi.org/10. 1556/CRC.36.2008

Cvijanović G, Đurić N, Marinković J, Đukić V, Dozet G, Petrović G, Cvijanović M (2017) Effect of different method of nutrition on wheat microflora of rhizosphere and yield of wheat. Inst PKB Agroecon 23(1-2):95-105

Cvijanović G, Subić J, Cvijanović D (2007) The significance of associative-nitrogen-fixators appliance in wheat production technology. Bucharest Academy of Economic Studies, Faculty of Agri-Food and Environmental Economics. Proceedings: "Sustainable Development of the Rural Space“, Bucharest International Conference, June 15-16, 2007, Academy of Economic Studies Publishing House, Bucharest, Romania: 96-101

Djuric N, Prodanovic S, Brankovic G, Djekic V, Cvijanovic G, Zilic S, Dragicevic V, Zecevic V, Dozet G (2018) Correlation-regression analysis of morphological-production traits of wheat varieties. Roman Bio Lett 23(2):13457-13465. https://doi.org/10.26327/ RBL2017.71

Donn S, John AK, Geetha P, Alan ER, Michelle W (2015) Evolution of bacterial communities in the wheat crop rhizosphere. Environ Microbiol 17(3):610-621. https://doi.org/10.1111/1462-2920. 12452

Đurić N, Kresović B, Glamočlija Đ (2015) Conventional and organic crop production systems. Monograph, PKB Agroekonomik Institute.

Đurić N, Cvijanović G, Dozet G, Branković G, Cvijanović V, Abuatwarat S (2017) Phenotypic changes in varietal reproduction of wheat. Agronomski glasnik, 5-6/2017, Croatian Society of Agronomists and European Seed Association Croatia, pp 259274. doi $10.33128 / \mathrm{ag}$

EBIC (2012) https://biostimulants.eu/

Evers AD (2000) Grain size and morphology: Implications for quality. Wheat structure, biochemistry and functionality, Schofield D. Royal Society of Chemistry, London, pp 19-24

Gregory P, George T (2011) Feeding nine billion: the challenge to sustainable crop production. J Exp Bot 62(15):5233-5239. https:// doi.org/10.1093/jxb/err232

Joner E, Skjerve E, Sundheim L, Tronsmo A, Wastson Y, Eckner K, Kapperud G, Jørgen FL, Truls N, Lucy R, Jan TR, Olaug TS, Line V (2019) Microorganisms in biostimulants. Eur J Nutr Food Saf, 9(3):310-311. https://doi.org/10.9734/ejnfs/2019/v9i330074

Kumar Baduru L, Sai Gopal DVR (2015) Effective role of indigenous microorganisms for sustainable environment, 3 Biotech 5(6):867876. https://doi.org/10.1007/s13205-015-0293-6

Lim T, Pak T, Jong C (1999) Yields of rice and maize as affected by effective microorganisms. In: Centre, INFR (ed), Proceedings of the 5th international conference on Kyusei nature farming and effective microorganisms for agricultural and environmental sustainability, Bangkok, Thailand, pp 92-98

Lotze-Campen H (2011) Regional climate impacts on agriculture in Europe: an overview. In: Yadav S (ed) Crop adaptation to climate change. Wiley-Blackwell, pp 78-83
Mayer J, Scheid S, Widmer F, Fließbach A, Oberholzer HR (2010) How effective are 'Effective microorganisms ${ }^{\circledR}$ (EM)'? Results from a field study in temperate climate. App Soil Eco 46:230-239

Mladenov N, Hristov N, Đurić V, Jevtić R, Jocković B (2014) Influence of precipitation at harvest time on winter wheat yield. In: Proceedings of the 45th conference of agronomists of serbia institute of field and vegetable crops Novi Sad, pp 27-31

Mohammadi R, Sadeghzadeh D, Armion M, Amri A (2011) Evaluation of durum wheat experimental lines under different climate and water regime conditions of Iran. Crop Pasture Sci 62:137-151. https://doi.org/10.1071/CP10284

Mohammadi R, Etminan A, Shoshtari L (2019) Agro-physiological characterization of durum wheat genotypes under drought conditions. Exp Agric 55(3):484-499. https://doi.org/10.1017/S0014 479718000133

Monaghan JM, Snape JW, Chojecki AJS, Kettlewell PS (2001) The use of grain protein deviation for identifying wheat cultivars with high grain protein concentration and yield. Euphytica 122(2001):309317. https://doi.org/10.1023/A:1012961703208

Moradgholi A, Mobasser H, Ganjali H. et al. (2021) WUE, protein and grain yield of wheat under the interaction of biological and chemical fertilizers and different moisture regimes. Cereal Res. Commun. https://doi.org/10.1007/s42976-021-00145-1

Nemeth T (2006) Nitrogen in the soil-plant system, nitrogen balances. Cereal Res Commun 34:61-65

Pena, R.J. (2007): Current and future trends of wheat quality needs. In: Buck HT, Nisi JE, Salomon N (eds) Wheat production in stressed environments. Springer, Berlin, pp 411-424

Roljević Nikolić S, Kovačević D, Cvijanović G, Dolijanović Ž, Marinković J (2018) Grain yield and rhizosphere microflora of alternative types of wheat in organic production. Rom Biotechn Lett 23(1):13301-13309. https://doi.org/10.26327/RBL2017.3

Salmabi KA, Lynette KA, Bede SM, Andrew SW, Kadambot HMS, Zakaria MS (2018) Response of wheat to a multiple species microbial inoculant compared to fertilizer application front. Plant Sci. https://doi.org/10.3389/fpls.2018.01601

Schenck zu Schweinsberg-Mickan M, Müller T (2009) Impact of effective microorganisms and other biofertilizers on soil microbial charakteristics, organic-matter decomposition and plant growth. J Plant Nutr Soil Sci. 172:704-712

Sharma A, Pathak A, Sahgal M, Meyer JM, Wray V, Johri BN (2007) Molecular characterization of plant growth promoting rhizobacteria that enhance peroxidase and phenylalanine ammonia-lyase activities in chile (Capsicum annuum L.) and tomato (Lycopersicon esculentum Mill.). Arch Microbiol 188:483-494.https://doi. org/10.1007/s00203-007-0270-5

Singh R, Behl RK, Jain P, Narula N, Singh KP (2007) Performance and gene effects for root characters and micronutrient uptake in wheat inoculated with arbuscular mycorrhizal fungi and Azotobacter chroococcum. Acta Agron Hung 55(3):325-330

Smutná P, Tokatlidis IS (2020) The influence of different soil types on rainfed wheat varieties for grain and protein yield. Cereal Res Commun 48:391-398. https://doi.org/10.1007/ s42976-020-00042-z

Teixeira FMCM, Galindo SBFS, Kondo SJM (2017) Inoculation with Azospirillum brasilense Improves Nutrition andIncreases Wheat Zield in Association with Nitrogen fertilization. https://www.intec hopen.com/books/wheat-improvement-management-and-utili zation/inoculation-with-azospirillum-brasilense-improves-nutri tion-and-increases-wheat-yield-in-association, https://doi.org/10. 1007/s13205-015-0293-6

Xia X, Ma C, Dong S, Xu Y, Gong Z (2017) Effects of nitrogen concentrations on nodulation and nitrogenase activity in dual root systems of soybean plants, Soil Sci Plant Nutr 63(5):470-482. https://doi.org/10.1080/00380768.2017.1370960 
Xiaohou S, Diyou L, Liang Z, Hu W, Hui W (2001) Use of EM-technology in agriculture and environmental management in China. Nat Farm Environ 2:9-18

Yue S, Wang C, Xu H, Dai J (2002) Effects of foliar application with effective microorganisms on leaf metabolism and seed yield in soybean. In: Sangkkara UR et al. (eds) Seventh international conference on Kyusei Nature Farming. Christchurch Polytechnic, New Zealand, pp 62-65

Zonuz FA, Gharavi Kouche Bagh P, Gasemi A (2014) Effects of combined use of bio-fertilizers and chemical fertilizers at different stages on physiological and morphological characters of navy bean. Indian J Fundam Appl Life Sci 4(3):423-427 